\title{
Neuronal Adenosine A2A Receptors Are Critical Mediators of Neurodegeneration Triggered by Convulsions
}

\author{
Paula M. Canas, ${ }^{1}$ Lisiane O. Porciúncula, ${ }^{1}{ }^{\circledR}$ Ana Patrícia Simões, ${ }^{1}$ Elisabete Augusto, ${ }^{1}$ Henrique B. \\ Silva, ${ }^{1}$ Nuno J. Machado, ${ }^{1}$ - Nélio Gonçalves, ${ }^{1}$ Tiago M. Alfaro, ${ }^{1}$ iDrancisco Q. Gonçalves, ${ }^{1}$ Inês M. \\ Araújo, ${ }^{1}$ 'Doana I. Real, ${ }^{1}$ Joana E. Coelho, ${ }^{2}$ Geanne M. Andrade, ${ }^{1}$ (D) Ramiro D. Almeida, ${ }^{1}$ Jiang-Fan \\ Chen, ${ }^{2}$ Attila Köfalvi, ${ }^{1}$ Paula Agostinho, ${ }^{1,3}$ and ${ }^{1}$ Rodrigo A. Cunha ${ }^{1,3}$
}

https://doi.org/10.1523/ENEURO.0385-18.2018

${ }^{1} \mathrm{CNC}$-Center for Neuroscience and Cell Biology, University of Coimbra, 3004-517 Coimbra, Portugal, ${ }^{2}$ Department of Neurology, Boston University School of Medicine, Boston, MA 02118, ${ }^{3}$ Faculty of Medicine, University of Coimbra, 3004-504 Coimbra, Portugal

\begin{abstract}
Neurodegeneration is a process transversal to neuropsychiatric diseases and the understanding of its mechanisms should allow devising strategies to prevent this irreversible step in brain diseases. Neurodegeneration caused by seizures is a critical step in the aggravation of temporal lobe epilepsy, but its mechanisms remain undetermined. Convulsions trigger an elevation of extracellular adenosine and upregulate adenosine $A_{2 A}$ receptors $\left(A_{2 A} R\right)$, which have been associated with the control of neurodegenerative diseases. Using the rat and mouse kainate model of temporal lobe epilepsy, we now tested whether $\mathrm{A}_{2 \mathrm{~A}} \mathrm{R}$ control convulsions-induced hippocampal neurodegeneration. The pharmacological or genetic blockade of $A_{2 A} R$ did not affect kainate-induced convulsions but dampened the subsequent neurotoxicity. This neurotoxicity began with a rapid $A_{2 A} R$ upregulation within glutamatergic synapses (within $2 h$ ), through local translation of synaptic $A_{2 A} R$ mRNA. This bolstered $A_{2 A} R$-mediated facilitation of glutamate release and of long-term potentiation (LTP) in CA1 synapses (4 h), triggered a subsequent synaptotoxicity, heralded by decreased synaptic plasticity and loss of synaptic markers coupled to calpain activation (12 h), that predated overt neuronal loss (24 h). All modifications were prevented by the deletion of $A_{2 A} R$ selectively in forebrain neurons. This shows that synaptic $A_{2 A} R$ critically control synaptic excitotoxicity, which underlies the development of convulsions-induced neurodegeneration.
\end{abstract}

Key words: adenosine; convulsions; neuroprotection; synapse; synaptotoxicity; synatic plasticity

\section{Significance Statement}

Epilepsy is an evolving disease where neurodegeneration is associated with the aggravation of subsequent convulsions. We now unveil that the upregulation of adenosine $A_{2 A}$ receptors $\left(A_{2 A} R\right)$ is paramount to link convulsions to neurodegeneration. This involves a translation of $A_{2 A} R$ within synapses to bolster the activity of excitatory glutamatergic synapses and triggers an excitotoxicity first of synapses, that later evolves into neurodegeneration through increased calpain activity. Accordingly, the pharmacological or genetic blockade of $\mathrm{A}_{2 \mathrm{~A}} \mathrm{R}$ arrested neurodegeneration, thus prompting $\mathrm{A}_{2 \mathrm{~A}} \mathrm{R}$ as novel targets to alleviate neuronal damage associated with epilepsy.

\section{Introduction}

Sclerotic temporal lobe epilepsy is the most common type of seizure disorder; it is an evolving disease pheno-

Received October 2, 2018; accepted October 7, 2018; First published December 17, 2018.

R.A.C. is a scientific advisor of the Institute for Scientific Information (ISIC). typically characterized by episodes of tonic-clonic convulsions that trigger adaptive changes and damage of brain tissue causing an aggravation of convulsions over 
time (Pitkänen and Sutula, 2002). Although this seizureinduced neurodegeneration is a key component of the pathophysiology of epilepsy, the underlying mechanisms are still unclear (Löscher and Brandt, 2010). One proposed participant in epileptogenesis is the adenosine modulation system (Dragunow, 1988; Dunwiddie, 1999; Boison, 2016): increased neuronal activity, and convulsions in particular, triggers a robust (During and Spencer, 1992) and sustained (Berman et al., 2000) elevation of the extracellular adenosine levels. Inhibitory adenosine $A_{1}$ receptors $\left(A_{1} R\right)$ are considered a major anti-convulsive system, since the acute administration of $A_{1} R$ agonists decreases seizures whereas the acute administration of $A_{1} R$ antagonists worsens seizures and the consequent neuronal damage (Dragunow, 1988; Dunwiddie, 1999). However, inhibitory $A_{1} R$ appear to have a limited time window of effectiveness since there is a decreased density and a reduced efficiency of $A_{1} R$ in afflicted brain regions after the induction of seizures (Young and Dragunow, 1994; Ochiishi et al., 1999; Rebola et al., 2003; but see Gouder et al., 2003). This matches the role of $A_{1} R$ as "gate-keepers" of brain tissue viability, since their activation increases the threshold for brain damage; however, $A_{1} R$ undergo a reduction of their density and efficiency on chronic brain dysfunction (Cunha, 2005). Accordingly, $A_{1} R$ efficiently control the spreading of ictal events to "naïve" regions (Fedele et al., 2006; Zeraati et al., 2006) and $A_{1} R$ lose efficiency over time to control neurodegeneration (von Lubitz, 2001; Cunha, 2016).

By contrast, the density of adenosine $A_{2 A}$ receptors $\left(A_{2 A} R\right)$ increases in limbic regions in different experimental models of epilepsy (Rebola et al., 2005a), as well as in sclerotic regions of patients with temporal lobe epilepsy (Barros-Barbosa et al., 2016). Cortical $A_{2 A} R$ are mostly located in synapses (Rebola et al., 2005b) but also in glia (Orr et al., 2009, 2015; Rebola et al., 2011), and their activation increases glutamate release (Lopes et al., 2002; Marchi et al., 2002), enhances NMDA receptor function (Rebola et al., 2008), and bolsters neuroinflammation (Rebola et al., 2011) in the hippocampus. This provides a mechanistic basis for the robust neuroprotection afforded

N.J.M., N.G., T.M.A., F.Q.G., I.M.A., J.I.R., J.E.C., G.M.A., R.D.A., A.K., P.A., and R.A.C. performed research; J.-F.C. contributed unpublished reagents/ analytic tools; P.M.C., L.O.P., A.P.S., E.A., H.B.S., N.J.M., N.G., T.M.A., F.Q.G., I.M.A., J.I.R., J.E.C., G.M.A., R.D.A., A.K., P.A., and R.A.C. analyzed data; R.A.C. wrote the paper.

This work was supported by Santa Casa da Misericórdia, Faculty of Medicine of the University of Coimbra (FMUC)/Santander-Totta, Coordenação de Aperfeiçoamento de Pessoal de Nível Superior (CAPES) / Fundação para a Ciência e a Tecnologia (FCT), and European Regional Development Fund through Centro 2020 (CENTRO-01-0246-FEDER-000010 and CENTRO-010246-FEDER-000010) and through FCT (POCl-01-0145-FEDER-031274).

Acknowledgements: We thank Patrício Soares da Silva (Bial) for the help in the initial kindling experiments.

Correspondence should be addressed to Rodrigo A. Cunha, CNC-Center for Neuroscience and Cell Biology, University of Coimbra, 3004-504 Coimbra, Portugal, E-mail: cunharod@gmail.com.

https://doi.org/10.1523/ENEURO.0385-18.2018

Copyright $\odot 2018$ Canas et al.

This is an open-access article distributed under the terms of the Creative Commons Attribution 4.0 International license, which permits unrestricted use, distribution and reproduction in any medium provided that the original work is properly attributed. by $A_{2 A} R$ antagonism in different noxious brain conditions (Chen et al., 2007; Cunha, 2016). Accordingly, the genetic deletion of $A_{2 A} R$ slows down epileptogenesis (El Yacoubi et al., 2001, 2009), but the role of $A_{2 A} R$ in the control of convulsions-induced neurodegeneration is still unclear (Lee et al., 2004; Rosim et al., 2011; Li et al., 2012).

This was now probed using kainate to trigger an acute convulsive period leading to subsequent neurodegeneration (Sperk et al., 1983; Coyle, 1987), modeling temporal lobe epilepsy (Ben-Ari, 1985). We report that the pharmacological or genetic blockade of $A_{2 A} R$ did not affect kainate-induced convulsions but dampened the subsequent neurotoxicity, which begins with maladaptive alterations in synapses.

\section{Materials and Methods}

\section{Animals}

Male Wistar rats and $\mathrm{C} 57 \mathrm{BI} / 6$ mice (8-10 weeks) were from Charles River. C57BL6 global $A_{2 A} R$-knock-out (KO) mice and forebrain $A_{2 A} R-K O$ mice were generated as previously described (Shen et al., 2008). Rodents were handled following European Union Directives (2010/63) on approval by the Ethical Committee of the Center for Neuroscience and Cell Biology (Orbea 78-2013).

\section{Kainate administration and evaluation of convulsions}

In rats, kainate (Tocris) was injected intraperitoneally at a dose of $10 \mathrm{mg} / \mathrm{kg}$, following our previous experience (Rebola et al., 2005a). The selective $A_{2 A} R$ antagonist SCH58261 (Tocris) was used at an effective dose of 0.05 $\mathrm{mg} / \mathrm{kg}$ (Lopes et al., 2004), administered intraperitoneally $30 \mathrm{~min}$ before kainate in most experiments, or $4 \mathrm{~h}$ after the extinction of convulsions in the last experimental protocol. $A_{2 A} R-K O$ and wild-type littermates or forebrain $A_{2 A} R-K O$ and floxed $A_{2 A} R-K O$ littermates (designated as wild-type), all with a C57BL6 background, were injected subcutaneously with either saline or kainate $(35 \mathrm{mg} / \mathrm{kg})$. The animals were observed for $3 \mathrm{~h}$ to score convulsions (Rebola et al., 2005a) according to the original Racine scale for rats or the Racine scale adapted to mice and then maintained in groups of three to four per cage.

\section{Amygdala kindling}

Amygdala kindling involved three groups: control, fully kindled and sham-operated rats. After one to two weeks of inserting an electrode in the amygdala, rats were stimulated twice a day (10 A.M. and 4 P.M.) with a 1-s train at $50 \mathrm{~Hz}$ with pulses of $1 \mathrm{~ms}$ and $500 \mu \mathrm{A}$, as previously described (Rebola et al., 2005a). After 24 d of stimulation, vehicle-treated rats were considered fully kindled (five consecutive sessions reaching stage 4-5). SCH58261 $(0.05 \mathrm{mg} / \mathrm{kg})$ was administered intraperitoneally twice a day, 30 min before each stimulation (or handling).

\section{Neuronal damage, astrogliosis, and microgliosis}

The rodents' brain was sectioned into 20 - $\mu$ m-thick coronal sections to analyze the general neuronal morphology using a cresyl violet staining of Nissl bodies (Kaster et al., 2015), cell damage using FluoroJade-C staining (Kaster et al., 2015), astrocytosis using GFAP immunoreactivity (Rebola et al., 2011; Kaster et al., 2015) with Cy3- 
conjugated anti-GFAP mouse antibodies (Sigma, 1:500), and microgliosis using either OX-42/CD11b immunohistochemistry (Rebola et al., 2011; Kaster et al., 2015) with mouse anti-CD11b antibodies (1:200; Serotec) or labeling with biotin-labeled tomato lectin (Dalmau et al., 2003; Vector Laboratories, 1:250). The integral of staining of FluoroJadeC (reporting degenerated neurons), CD11b (staining microglia), or GFAP (staining astrocytes) was counted in three regions of $50 \times 50 \mu \mathrm{m}$ in three sections per animal. These windows were selected free hand and placed in the stratum pyramidale (FluoroJadeC) or stratum radiatum (GFAP, CD11b) of the CA1 or CA3 regions, and a measure was taken in the anterior commissure as background.

To assess the localization of $A_{2 A} R$ in microglia-like cells, brain sections from saline- or kainate-treated mice were collected $24 \mathrm{~h}$ after kainate injection and incubated with a combination of mouse anti- $A_{2 A} R$ (1:500; Millipore Biotechnology) and rabbit anti-CD11b (1:100; Serotec) antibodies, followed by incubation with Alexa Fluor-labeled secondary antibodies (1:200; Invitrogen). Nuclei were stained with Hoechst $33342(2 \mu \mathrm{g} / \mathrm{ml})$ and sections were analyzed in a confocal microscope (LSM510; Zeiss).

\section{Exposure of synaptosomes to kainate}

Hippocampal synaptosomes (purified synapses), prepared as previously described (Rebola et al., 2005b; Canas et al., 2014; Kaster et al., 2015), were incubated for 2 $\mathrm{h}$ at $37^{\circ} \mathrm{C}$ in the absence or presence of kainate $(5 \mu \mathrm{M})$, without or together with cycloheximide $(100 \mu \mathrm{M})$.

\section{Receptor binding assay}

The density of $A_{2 A} R$ was estimated by radioligand binding assays using a supramaximal concentration of ${ }^{3} \mathrm{H}$ SCH58261 (6 nM; offered by E. Ongini, Schering-Plow, Italy), as previously described (Rebola et al., 2005b; Kaster et al., 2015). Specific binding was determined by subtraction of non-specific binding, measured using $3 \mu \mathrm{M}$ XAC (Tocris).

\section{Immunocytochemistry}

The immunocytochemical detection of $A_{2 A} R$ in individual glutamatergic and GABAergic nerve terminals was conducted as previously described (Canas et al., 2014; Kaster et al., 2015) by double-labeling with goat anti- $A_{2 A} R$ (1:200, Santa Cruz Biotechnology), together with either guinea-pig anti-vGluT1 (1:500, Synaptic Systems) or guinea-pig anti-vGAT (1:200, Synaptic Systems) antibodies, followed by incubation with Alexa Fluor-labeled secondary antibodies (1:500, Invitrogen). The preparations were examined under a Zeiss Imager Z2 fluorescence microscope and each coverslip was analyzed by counting three different fields and in each field an average of 500 individualized elements (Canas et al., 2014).

\section{Western blot analysis}

Western blot analysis was conducted by SDS-PAGE using synaptosomal membranes to evaluate synaptic markers, using antibodies against syntaxin-I (1:5000; Sigma), SNAP25 (1:2000; Sigma) and vGluT1 (1:5000; Millipore Bioscience Research Reagents), as previously described (Canas et al., 2014; Kaster et al., 2015). Membranes were reprobed for $\alpha$-tubulin (1:1000; Abcam) as a loading control.

\section{Glutamate release}

Rat hippocampal slices (Costenla et al., 2011) obtained at $3 \mathrm{~h}$ after administering saline or kainate $(10 \mathrm{mg} / \mathrm{kg})$ to trigger Racine-stage 4-5 convulsions, recovered for 45 min, before being loaded for $15 \mathrm{~min}$ at $37^{\circ} \mathrm{C}$ with ${ }^{3} \mathrm{H}$ glutamate $(2 \mu \mathrm{M}$; specific activity, $0.319 \mathrm{Ci} / \mathrm{mol})$ in the presence of aminooxyacetic acid (100 $\mu \mathrm{M}$; Sigma). Slices were then superfused $(0.7 \mathrm{ml} / \mathrm{min})$ for $10 \mathrm{~min}$ and next stimulated for $3 \mathrm{~min}$ with $20 \mathrm{mM} \mathrm{K}^{+}$. The tritium content of the collected effluent samples and of the harvested slices was counted and the fractional release (FR\%) calculated for each sample as the percentage of ${ }^{3} \mathrm{H}$-glutamate content in the slice (Lopes et al., 2002).

\section{Neuronal culture in microfluidic chambers}

Hippocampal neurons were cultured from 17- to 19-dold Wistar rat embryos and plated on microfluid chambers as previously described (Taylor et al., 2005; Pinto et al., 2016). The dissociated neurons were placed in one chamber and only the axons can grow (around DIV4/5) through the microgrooves into the opposite chamber. Neurons were cultured at $37^{\circ} \mathrm{C}$ in a $5 \% \mathrm{CO}_{2}$ humidified atmosphere in Neurobasal medium with $\mathrm{B}_{27}$ supplement, glutamate $(25 \mathrm{mM})$, glutamine $(0.5 \mathrm{mM})$, and gentamicin $(0.12$ $\mathrm{mg} / \mathrm{ml}$ ).

\section{PCR analysis}

Total RNA was extracted from the hippocampus with MagNA Lyser (Roche) to calculate the mRNA expression of $A_{2 A} R, C D 11 b$ and lba1 by real-time PCR using a SYBR Green I kit (Roche) and the comparative cycle threshold method with glyceraldehide-3'-phosphate dehydrogenase as housekeeping, as previously described (Costenla et al., 2011; Rebola et al., 2011). Non-quantitative PCR to detect $A_{2 A} R$ mRNA was also conducted in cDNA samples from synaptosomes (previously incubated with RNase for $30 \mathrm{~min}$ at $37^{\circ} \mathrm{C}$ ) or striatal tissue from rats, or a scraped collection of axon terminals or of cell bodies from rat hippocampal neurons cultured in different microfluidic chambers, using histone-1 mRNA as nuclear control and $\beta$-actin mRNA as synaptic control.

\section{Electrophysiological recordings}

Recordings of excitatory synaptic transmission and plasticity were performed in superfused hippocampal slices (400 $\mu \mathrm{m}$ thick), as previously described (Costenla et al., 2011; Kaster et al., 2015). Briefly, Schaffer fibers were stimulated every $15 \mathrm{~s}$ to evoked field EPSPs (fEPSPs) recorded in the CA1 stratum radiatum to measure the fEPSP slope. Long-term potentiation (LTP) was induced with a high-frequency train $(100 \mathrm{~Hz}$ for $1 \mathrm{~s})$ and was quantified as the percentage change between the fEPSP slopes $60 \mathrm{~min}$ after and $15 \mathrm{~min}$ before the train. LTP amplitude was compared in different slices from the same animal in the absence and presence of a supramaximal concentration (50 nM) of SCH58261. 
A

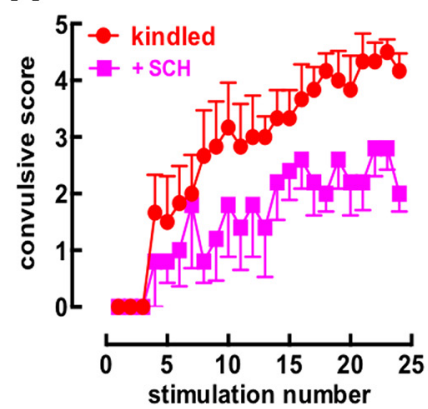

B

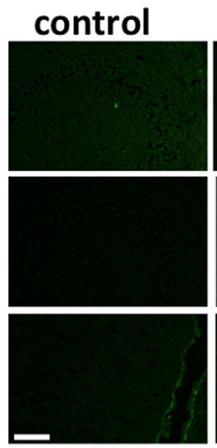

$\mathrm{SCH}$

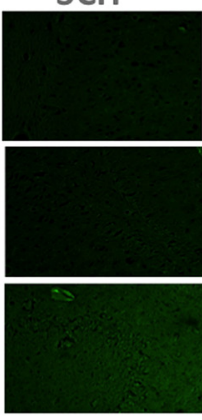

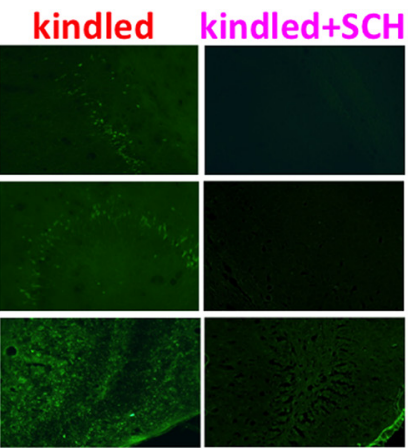

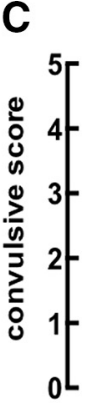

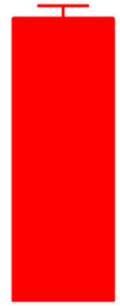

KAI

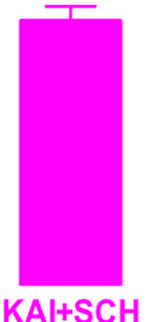

F
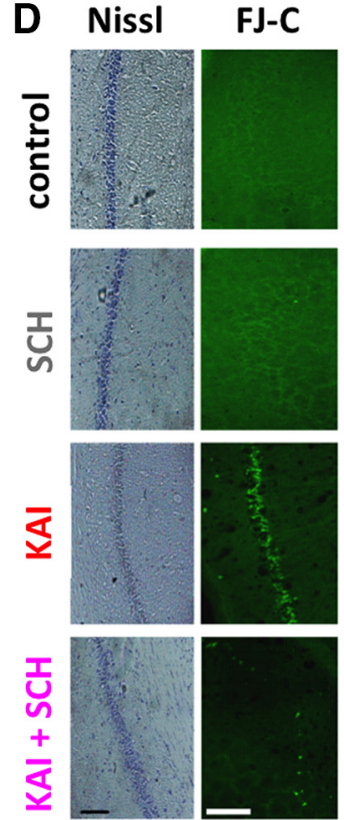
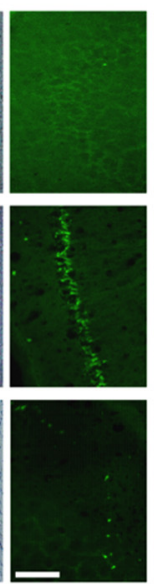
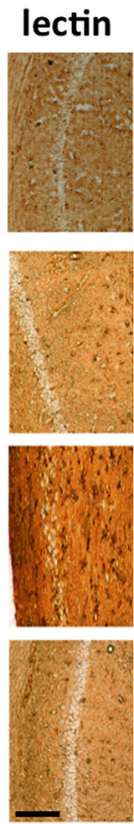
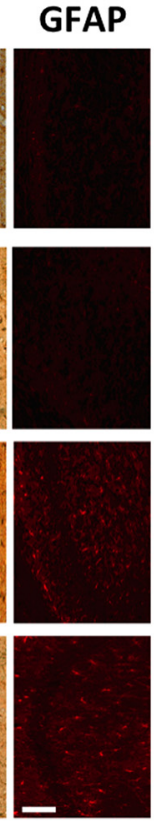

E

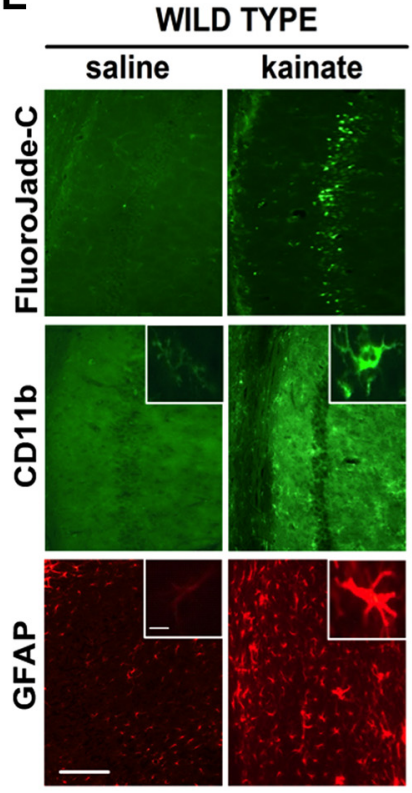

$A_{2 A}$ R KNOCKOUT
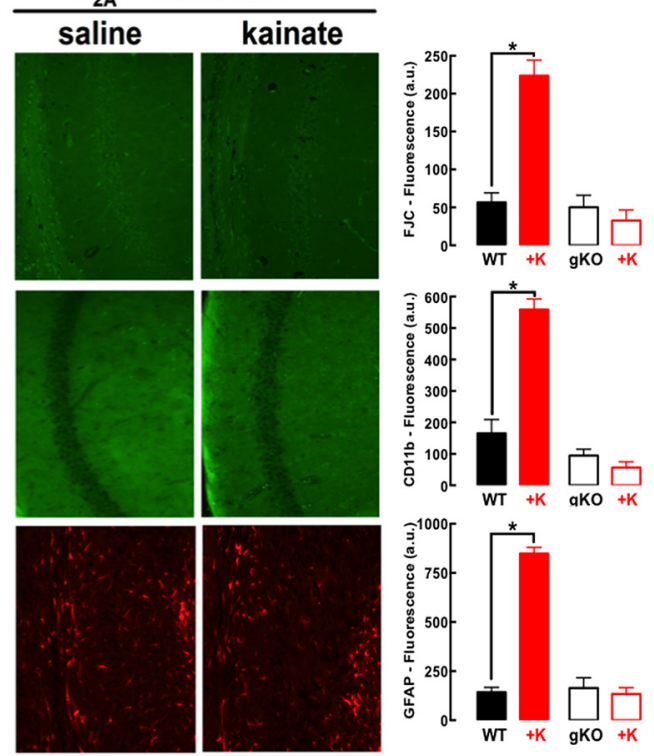
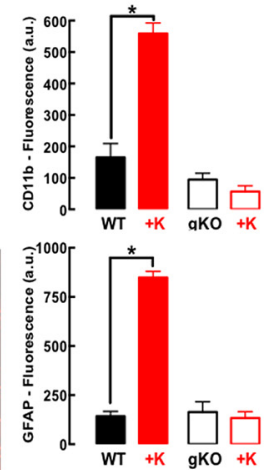

Figure 1. The pharmacological blockade or genetic elimination of adenosine $A_{2 A} R$ prevents hippocampal damage caused by either amygdala kindling or kainate administration, while only attenuating the evolution of convulsions. $\boldsymbol{A}$, Male Wistar rats were implanted with electrodes in the amygdala and stimulation twice daily progressively increased the severity of convulsions until triggering a fully kindled state $(n=7)$, which was reduced by a selective $A_{2 A} R$ antagonist SCH58261 (0.05 mg twice daily; $\left.n=8\right)$. B, Rats were killed $5 \mathrm{~d}$ after reaching fully kindled state and only the kindled rats treated with saline displayed degenerated cells, identified by FluoroJade-C labeling, in all hippocampal fields, whereas neither control nor SCH58261-treated rats, irrespective of being kindled or not, displayed FluoroJade-C staining. C, On intraperitoneal administration of kainate (KAl, $10 \mathrm{mg} / \mathrm{kg} ; n=11)$, rats treated with 0.05 $\mathrm{mg} / \mathrm{kg}$ of SCH58261 (KAl+SCH, $n=12$ ) displayed a similar pattern of acute convulsions (within 15 min and lasting no $>75$ min after $\mathrm{KAl}$ ). D, However, SCH58261 prevented the histologic modifications observed in the hippocampus $24 \mathrm{~h}$ after kainate administration, namely, the dispersion of pyramidal cell layer with Nissl staining, the appearance of ruptured cells stained with FluoroJade-C (FJ-C), the modification of microglia staining with tomato lectin, and the increase of the number and density of GFAP-stained element compatible with astrogliosis. $\boldsymbol{E}, \boldsymbol{F}$, The administration of kainate $(35 \mathrm{mg} / \mathrm{kg}, \mathrm{sc})$ to wild-type (WT) C57BI6 mice ( $n=11)$ triggered a convulsive period followed by the appearance of degenerated cells stained with FluoroJade-C together with a microgliosis and astrogliosis concluded from the altered staining of hippocampal sections with CD11b and GFAP, respectively; notably, the same exposure to kainate $(+K)$ of littermates with a genetic deletion of $A_{2 A} R\left(A_{2 A} R-K O, g K O\right)$ triggered a similar intensity of convulsions, which did not evolve into an evident pattern of neurodegeneration, microgliosis, or astrogliosis in the hippocampus after $24 \mathrm{~h}$ ( $n=$ 10). Calibration bars in each photograph are $100 \mu \mathrm{m}$, except the insets, which display higher magnifications of either astrocytes or microglia (calibration bar $=10 \mu \mathrm{m}$ ). Data are mean \pm SEM; $* p<0.05$ between bars or versus control (saline).

\section{Experimental design and statistical analyses}

Data are mean \pm SEM values. Data with one condition and one variable (effects of $A_{2 A} R$ antagonist or of kainate treatment) were analyzed with Student's $t$ test. Data with more than one variable (effect of $A_{2 A} R$ blockade on kainate treatments) were analyzed with a two-way ANOVA followed by Newman-Keuls post hoc tests with a significance level was $95 \%$.

\section{Results}

\section{$A_{2 A} R$ blockade attenuates epileptogenesis on amygdala kindling}

Rats subjected to daily electrical stimulation of the amygdala slowly began displaying convulsions that escalated over continuous sessions of electrical stimulation (kindling; Fig. 1A). Both the onset and evolution of con- 
vulsions was attenuated in rats treated with the selective $\mathrm{A}_{2 \mathrm{~A}} \mathrm{R}$ antagonist SCH58261 (0.05 mg/kg; Fig. $\left.1 A\right)$. After $24 \mathrm{~d}$ of stimulation, the hippocampus displayed neurodegenerative features, as heralded by the presence of cells stained with FluoroJade-C in all subregions only in kindled but not in sham-operated (control) or SCH58261-treated rats, irrespective of being kindled or not (Fig. $1 B$ ). Thus, $A_{2 A} R$ blockade blunted convulsions-induced neurodegeneration while it only attenuated the escalating convulsive profile; this suggests that this prominent neuroprotection might underlie the anti-epileptogenic effect of $A_{2 A} R$ antagonists previously reported in other animal models of epilepsy (El Yacoubi et al., 2009; Li et al., 2012). However, since tinkering with $A_{2 A} R$ affected both abnormal excitability and neuronal damage, which are tightly intertwined, we had to turn to another model of epilepsy allowing a separation of abnormal excitability from the subsequent damage.

\section{$A_{2 A} R$ blockade does not affect kainate-induced convulsions but prevents subsequent neurodegeneration}

To confirm this hypothesis, we used kainate administration, which triggers a period of intense convulsions followed by neuronal damage evident after $24 \mathrm{~h}$ and evolving with time (Sperk et al., 1983). In contrast to the amygdala kindling model, the kainate model of convulsions, allows to temporally disentangle convulsions and neurodegeneration. Kainate $(10 \mathrm{mg} / \mathrm{kg}$, i.p.) triggered convulsions reaching a maximal intensity of $4-5$ in the Racine's scale within 40-60 min, which had similar intensities in saline- and SCH58261-treated rats (Fig. 1C). This similar duration and intensity of convulsions tentatively allows isolating the effect of $A_{2 A} R$ on neurodegeneration. Kainate damaged hippocampal pyramidal neurons, visible after $24 \mathrm{~h}$ as a decreased Nissl staining and appearance of FluoroJade-C-stained cells in CA1 area (Fig. 1D), which was more evident than in CA3 region (data not shown; see also Sperk et al., 1983), together with an astrogliosis (4-fold more GFAP-stained profiles, $n=9$ ) and microgliosis (increased number of profiles labeled with tomato lectin displaying thicker processes, i.e., "activated" microglia; Dalmau et al., 2003). These modifications were more pronounced $7 \mathrm{~d}$ after kainate injection (data not shown), in accordance with the evolution of limbic lesions following convulsions (Sperk et al., 1983). SCH58261 (0.05 mg/kg) virtually eliminated kainateinduced neuronal damage and glia-related modifications, indicative of astrogliosis and microgliosis in the hippocampus (Fig. 1D).

We next ascertained whether $A_{2 A} R$ also control convulsionsinduced neurodegeneration in mice. Differently from rats, mice required a subcutaneously treatment with a higher dose of kainate $(35 \mathrm{mg} / \mathrm{kg})$ to convulse with a maximal intensity of 4-6 in the modified Racine's scale within 45-70 min. Again, in all experimental groups, we always confirmed that mice displayed similar intensity and duration of convulsions to tentatively isolate the effect of $A_{2 A} R$ on neurodegeneration. Kainate damaged hippocampal pyramidal neurons, visible after $24 \mathrm{~h}$ as a decreased Nissl staining, as well as an appearance of FluoroJade-C-stained cells in the
Cornu Ammonis. Notably, mice with genetic $A_{2 A} R$ deletion (global $\mathrm{A}_{2 \mathrm{~A}} \mathrm{R}-\mathrm{KOs}$ ) displayed a convulsive profile (4.30 \pm $0.30, n=10)$ similar $\left(F_{(1,37)}=2.62 ; p=0.11\right)$ to wild-type littermates (4.90 $\pm 0.23, n=10)$, but did not display the kainate-induced neuronal damage, astrogliosis, or microgliosis that were present in wild-type mice (Fig. 1E,F). Similarly, SCH58261-treated mice did not display kainateinduced damage although they convulsed similarly to vehicle-treated mice (data not shown).

\section{$A_{2 A} R$ are upregulated in glutamatergic synapses through a local translation}

Neuroinflammation and glutamate excitotoxicity are involved in epilepsy-associated neurodegeneration (Coyle, 1987; Devinsky et al., 2013) and brain insults can upregulate $A_{2 A} R$ in both microglia and synapses (Cunha, 2016), whereas the upregulation of $A_{2 A} R$ in astrocytes occurs later in processes of neurodegeneration (Orr et al., 2015; Ogawa et al., 2018). Thus, we tested whether convulsions upregulated $A_{2 A} R$ in microglia and/or in synapses. At $24 \mathrm{~h}$ after kainate administration, mouse hippocampal cellular elements labeled with the microglia marker CD11b displayed increased immunoreactivity for both $C D 11 b$ and $A_{2 A} R$ (Fig. $2 A, B$ ), whereas there was no observable $A_{2 A} R$ immunoreactivity in hippocampal sections collected from $\mathrm{A}_{2 \mathrm{~A}} \mathrm{R}-\mathrm{KO}$ mice challenged with kainate (data not shown). However, PCR analysis of hippocampal extracts from kainate-treated mice revealed a different time course for the upregulation of $A_{2 A} R$ and for the microglia markers CD11b and Iba1 (Fig. 2C,D), which are rapidly upregulated by triggers of neuroinflammation such as LPS, to inform on dynamic adaptive changes of microglia function (Rebola et al., 2011). CD11b and Iba1 mRNA levels only increased after 12-24 h (Fig. $2 C$ ), whereas $A_{2 A} R$ binding density increased in hippocampal synaptic membranes as early as $2 \mathrm{~h}$ (Fig. $2 D$ ). This suggests that $A_{2 A} R$ upregulation might occur in cellular compartments other than microglia. In fact, $2 \mathrm{~h}$ after kainate administration, an early $A_{2 A} R$ upregulation was evident in glutamatergic synapses, as gauged by increased $A_{2 A} R$ immunoreactivity in vGluT1positive synaptosomes of kainate-treated versus salineinjected mice ( $t=5.788$; df $=10 ; p=0.0002$; Fig. 2E,F). This $A_{2 A} R$ upregulation did not occur in GABAergic synapses identified as vGAT-positive $(t=0.232 ; \mathrm{df}=10 ; p=$ 0.82).

The speed of this synaptic $A_{2 A} R$ upregulation and the distance between synapses and the nucleus in pyramidal hippocampal neurons prompted a possible involvement of local translation within synapses. This would imply the presence of $A_{2 A} R$ mRNA in synapses. This was identified by qPCR in hippocampal synaptosomes (Fig. 2G) and confirmed in axonal ends of hippocampal neurons cultured in microfluidic chambers (Fig. $2 H$ ), which physically separate cell bodies from axon terminals (Taylor et al., 2005; Pinto et al., 2016). Moreover, exposure of synaptosomes (purified synapses, without nuclei) to kainate $(5 \mu \mathrm{M}$, for $2 \mathrm{~h}$ ) increased $\mathrm{A}_{2 \mathrm{~A}} \mathrm{R}$ binding density $(t=2.609 ; \mathrm{df}=8 ; p$ $=0.031)$, an effect prevented by $100 \mu \mathrm{M}$ cycloheximide, a protein synthesis inhibitor $(t=0.7845 ; \mathrm{df}=6 ; p=0.463$; Fig. 21). This local synaptic translation of $A_{2 A} R$ mRNA provides a 
A
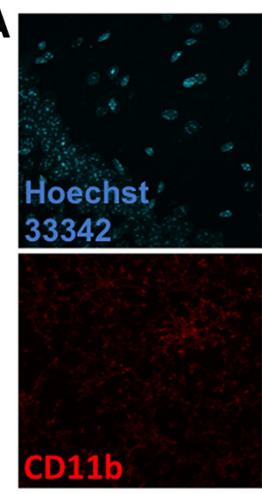

C

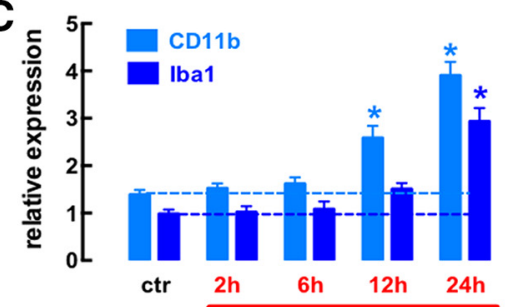

B

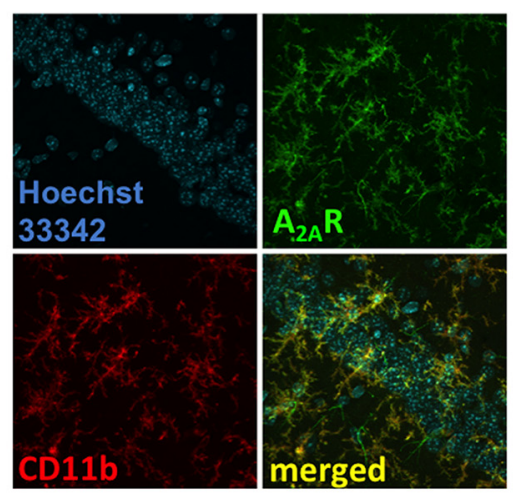

D

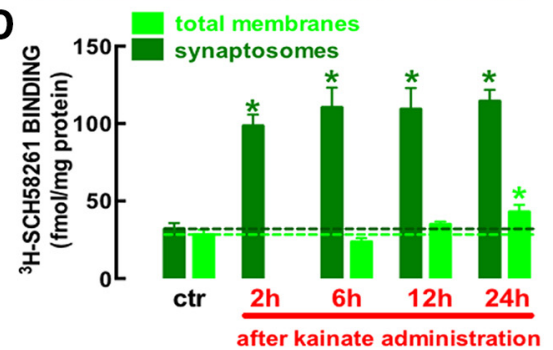
after kainate administration

E after kainate administration
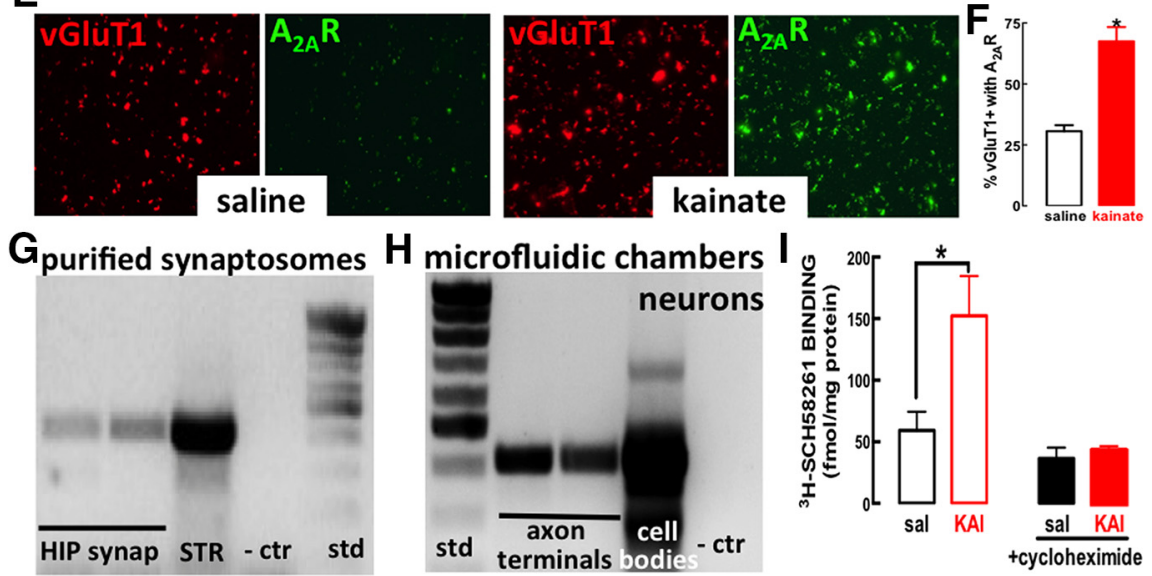

Figure 2. $A$ convulsive period triggers an early upregulation of $A_{2 A} R$ in glutamate synapses, likely involving a local translation of synaptic $A_{2 A} R$ mRNA, and a delayed upregulation of $A_{2 A} R$ in modified microglia cells in the hippocampus. $\boldsymbol{A}$, The immuno-density of the microglia marker $C D 11 b$ and of $A_{2 A} R$ were low in hippocampal sections from saline-treated mice, whereas they were increased and colocated circa $22 \mathrm{~h}$ after a convulsive period triggered by the subcutaneous injection of $35 \mathrm{mg} / \mathrm{kg} \mathrm{kainate}(\boldsymbol{B}$; confocal images representative of $n=3$ mice per group). $\boldsymbol{C}$, Kainate-induced convulsions triggered an increase of mRNA levels of CD11b and Iba1, characteristic of reactive microglia, only after $12-24 \mathrm{~h}$ in mouse hippocampal extracts ( $n=6$ for each time point). $\boldsymbol{D}$, In contrast, an increased $A_{2 A} R$ density was observed in synaptosomes (purified synapses) as soon as $2 \mathrm{~h}$ after kainate injection, whereas an $A_{2 A} R$ binding density was only upregulated in total membranes after $24 \mathrm{~h}$ in the hippocampus $(n=5$ for each determination, except $n=$ 6 at $24 \mathrm{~h}$ ). $\boldsymbol{E}, \boldsymbol{F}$, Kainate-induced $\mathrm{A}_{2 \mathrm{~A}} \mathrm{R}$ upregulation was evident in glutamate synapses, as gauged by the kainate-induced increased $A_{2 A} R$ immunoreactivity in hippocampal synaptosomes immuno-positive for vesicular glutamate transporter type 1 (vGluT1; $n=6$ ). $\mathbf{G}$, $A_{2 A} R$ mRNA was identified in purified synaptosomes from the hippocampus (HIP), similarly to its presence in rat striatal extracts (STR) of the rat brain $(n=3)$. $\boldsymbol{H}$, The synaptic localization of $A_{2 A} R$ mRNA was confirmed in a pure axonal preparation from hippocampal neurons cultured in microfluidic chambers, which ensures a physical segregation of axon terminals and cell bodies $(n=2)$. $I$, The contribution of the local translation of synaptic $A_{2 A} R$ mRNA for the kainate-induced upregulation of $A_{2 A} R$ was concluded by the ability of cycloheximide $(n=4)$ to prevent the increase of $A_{2 A} R$ binding density in synaptosomes exposed for $2 \mathrm{~h}$ to $5 \mu \mathrm{M}$ kainate $(n=5)$. Data are mean $\pm \mathrm{SEM} ; * p<0.05$ between bars or versus control (saline, sal).

rationale for the rapid $A_{2 A} R$ upregulation selectively in synapses shortly after noxious stimuli.

\section{Convulsions bolster $A_{2 A} R$-mediated potentiation of glutamatergic synapse function}

To probe the impact of $A_{2 A} R$ upregulation, we first compared glutamate release from hippocampal slices collected from rats killed $3 \mathrm{~h}$ after the administration of either vehicle or kainate (Fig. $3 A$ ). SCH58261 (50 nM) inhibited the $\mathrm{K}^{+}(20 \mathrm{mM})$-induced glutamate release in the kainate-treated group ( $t=2.735 ; \mathrm{df}=7 ; p=0.029)$, but not in the saline group ( $t=1.435 ; \mathrm{df}=7 ; p=0.195$; Fig. $3 A, B$ ), indicating a greater tonic activation of $A_{2 A} R$ bolstering glutamate release after kainate-induced convul- 
A

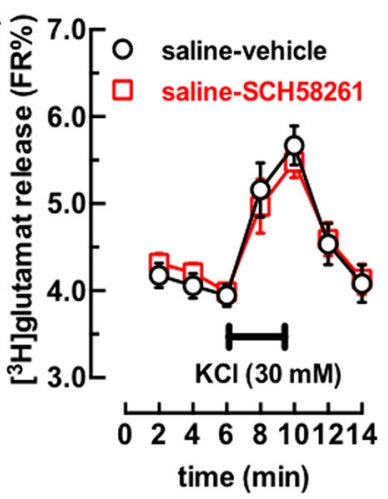

C

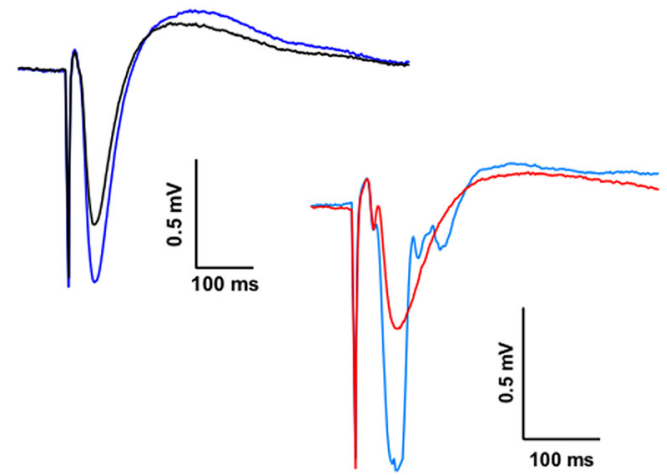

B

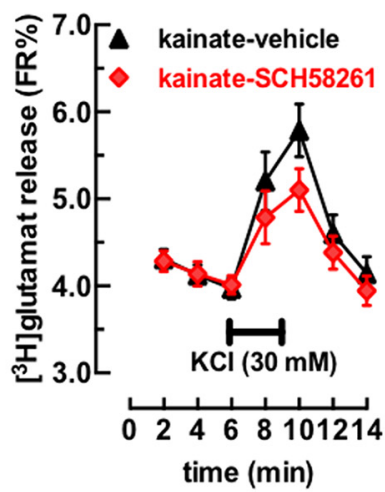

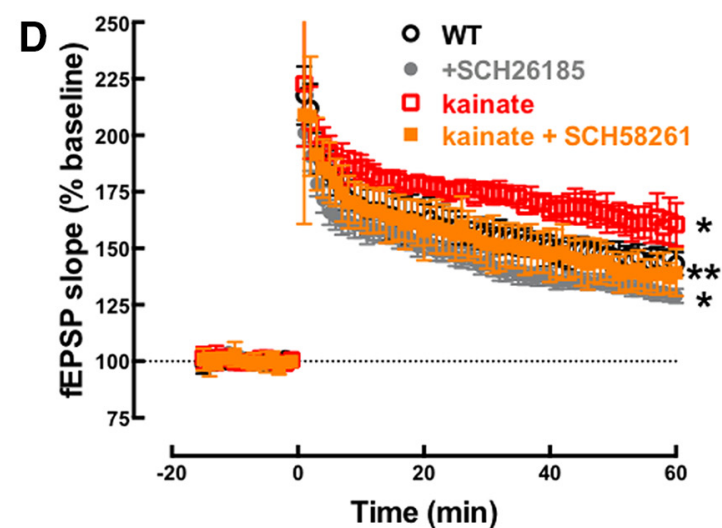

Figure 3. A convulsive period bolsters the function of synaptic $A_{2 A} R$ in glutamatergic synapses. $\boldsymbol{A}, \boldsymbol{B}, A_{2 A} R$ blockade with SCH58261 $(50 \mathrm{nM})$ did not modified the depolarization-evoked release of glutamate (i.e., on augmentation of extracellular $\mathrm{K}^{+}$as indicated by the horizontal insert line) from hippocampal synaptosomes from saline-treated mice (left panel, $n=8$ ), but increased glutamate release from synaptosomes collected from convulsing rats $2 \mathrm{~h}$ after kainate administration (10 $\mathrm{mg} / \mathrm{kg}$, i.p.; right panel, $n=6)$. $\boldsymbol{C}, \boldsymbol{D}$, The amplitude of LTP, triggered by high-frequency stimulation $(100 \mathrm{~Hz}$ for $1 \mathrm{~s})$ of afferent Schaffer fibers, was larger in CA1 synapses from hippocampal slices collected $4 \mathrm{~h}$ after the administration of kainate $(n=6)$ than in saline-treated mice $(n=5)$. C, Pairs of superimposed fEPSP recorded $10 \mathrm{~min}$ before (black and red traces) and $60 \mathrm{~min}$ after the high-frequency train (dark or light blue traces) in slices from saline-treated mice (left pair) or $4 \mathrm{~h}$ after kainate administration (right pair). $\boldsymbol{D}$, Time course of average fEPSPs before and after application of the high-frequency train (at time 0 ) in slices from control mice (black symbols), the aberrantly large LTP in slices collected $4 \mathrm{~h}$ after kainate administration (red symbols) and the ability of $50 \mathrm{nM} \mathrm{SCH58261}$ to bring LTP amplitude back to control levels in these slices collected $4 \mathrm{~h}$ after kainate injection (orange symbols). This indicates that convulsions-induced aberrant synaptic plasticity is due to overfunctioning of $A_{2 A} R$. Data are mean $\pm S E M ; * p<0.05$ versus control (saline in $\boldsymbol{B}$; WT - wild type in $\boldsymbol{D}) ; * * p<0.05$ comparing kainate versus kainate $+\mathrm{SCH} 58261$ in $\boldsymbol{D}$.

sions. We next evaluated the $A_{2 A} R$-mediated selective control of LTP in CA1 pyramid synapses (Costenla et al., 2011). LTP amplitude was larger in slices $4 \mathrm{~h}$ after kainate treatment than in saline-treated mice $\left(F_{(1,20)}=11.65 ; p=\right.$ 0.0028; Fig. 3C,D). Moreover, $A_{2 A} R$ blockade caused a larger decrease of LTP amplitude $(37.6 \pm 4.4 \%)$ in slices from kainate- than saline-treated mice $(25.6 \pm 3.9 \%$; interaction: $F_{(1,20)}=5.01 ; p=0.048$; Fig. $3 D$ ), bringing LTP amplitude in slices from kainate-treated mice (38.30 $\pm 3.35 \%$ above baseline) to values close to control (43.78 $\pm 2.08 \%)$. This indicates that convulsions trigger a rapid glutamatergic hyperfunction through an increased $A_{2 A} R$ modulation.

To confirm the selective involvement of neuronal $A_{2 A} R$, we exploited forebrain $A_{2 A} R-K O$ mice, which lack $A_{2 A} R$ selectively in principal neurons of the forebrain (Shen et al., 2008). In forebrain $A_{2 A} R-K O$ mice, kainate failed to alter LTP amplitude $\left(F_{(1,17)}=0.028 ; p=0.86\right)$ and SCH58261 (50 nM) was also devoid of effects on LTP amplitude $\left(F_{(1,17)}=0.457 ; p=0.50 ;\right.$ Fig. $\left.4 A\right)$. Additionally, hippocampal cellular damage, astrogliosis, and microgliosis were present in wild-type littermates but were not observed in forebrain $A_{2 A} R-K O$ mice $24 \mathrm{~h}$ after kainate administration (Fig. $4 B, C$ ), although the intensity of convulsions in wild-type mice $(4.80 \pm 0.20$, Racine's modified scale) was similar $\left(F_{(1,38)}=0.1293 ; p=0.72\right)$ to that of forebrain $A_{2 A} R-K O$ mice $(4.70 \pm 0.20)$. These findings directly support a key role of neuronal $A_{2 A} R$ in the control of neurodegeneration triggered by a convulsive episode.

\section{$A_{2 A} R$-induced glutamate hyperfunction triggers a subsequent dysfunction of glutamate synapses}

To clarify the evolution from an initial $A_{2 A} R$-mediated bolstering of glutamatergic activity (at $4 \mathrm{~h}$ ) into subsequent neuronal damage (at $24 \mathrm{~h}$ ), we characterized alterations present $12 \mathrm{~h}$ after kainate administration. The kainate-induced increase of LTP amplitude at $4 \mathrm{~h}$ (Fig. 3D) was transformed into an inhibitory effect at $12 \mathrm{~h}(t=$ 
A
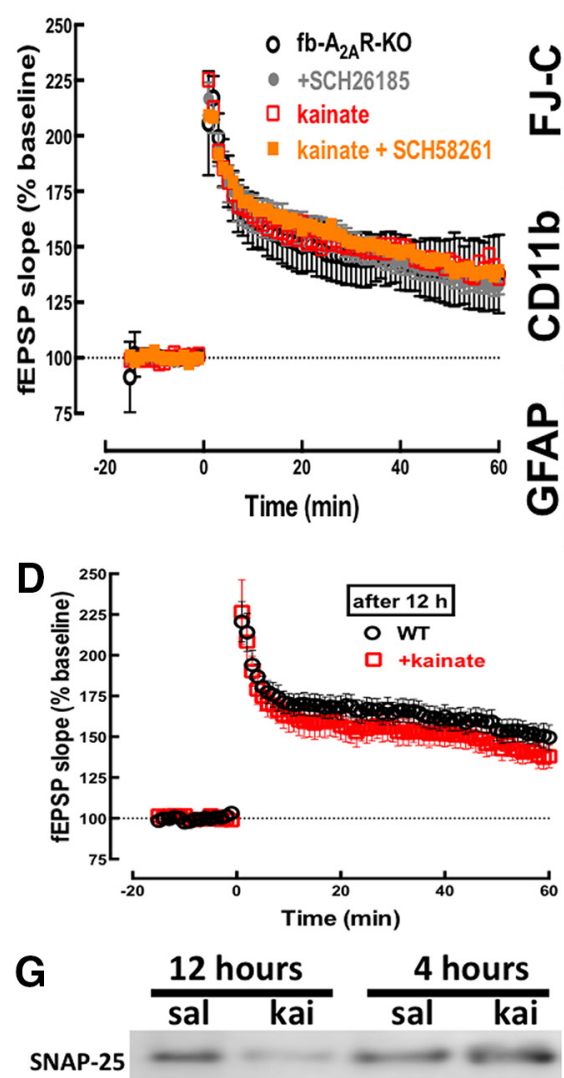

syntaxin-I

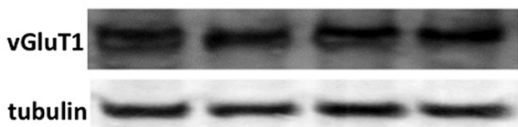

B

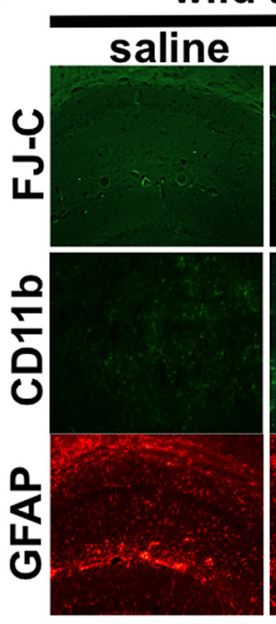

E

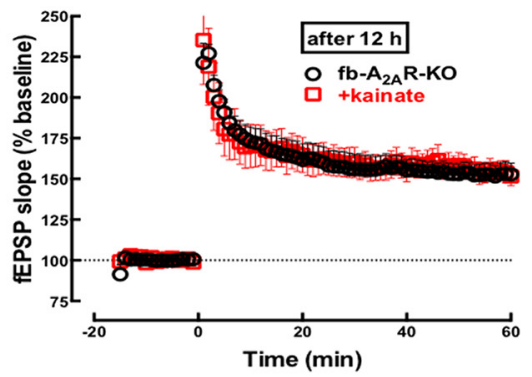

forebrain $A_{2 A} R K O$
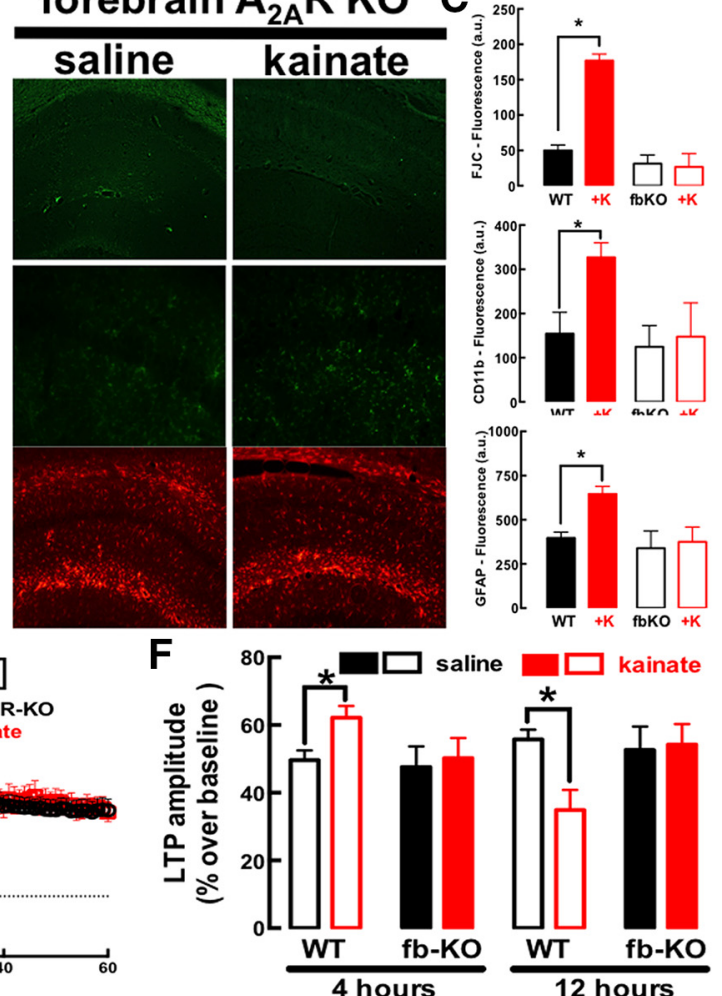

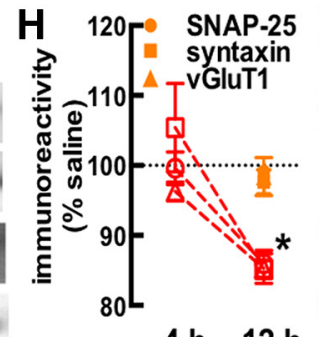

$4 \mathrm{~h}$

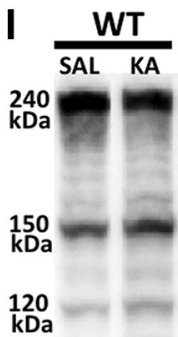

kDa
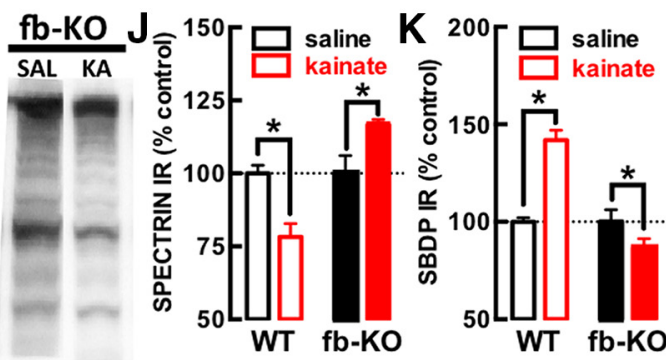

Figure 4. Neuronal $A_{2 A} R$ are critical to convert the initial convulsions-induced glutamate hyperfunctioning into a subsequent dysfunction and loss of glutamate synapses with the activation of calpains. A, $\boldsymbol{B}$, Absence of alteration of the high-frequency train (100 $\mathrm{Hz}$ for $1 \mathrm{~s}$, applied at time 0)-induced LTP of fEPSP recorded in the CA1 stratum radiatum on stimulation of afferent Schaffer fibers in hippocampal slices collected $4 \mathrm{~h}$ after the induction of a convulsive period on subcutaneous administration of $35 \mathrm{mg} / \mathrm{kg} \mathrm{kainate}$ to mice with a genetic deletion of $A_{2 A} R$ selectively in forebrain neurons (fb- $\left.A_{2 A} R-K O, n=6\right)$. B, $\boldsymbol{C}$, Likewise, fb- $A_{2 A} R-K O$ mice analyzed $24 \mathrm{~h}$ after the injection of kainate did not display neuronal damage (FluoroJade-C, FJ-C), microgliosis (CD11b immunoreactivity) or astrogliosis (GFAP immunoreactivity), which was present in "wild-type" littermates $(n=8-10$ mice per group). The conversion from the initial convulsions-induced hyperfunctioning of glutamate synapses into neurodegeneration first involved a synaptic dysfunction, as shown $(\boldsymbol{D})$ by the lower amplitude of LTP in hippocampal slices collected $12 \mathrm{~h}$ after the administration of kainate to trigger a convulsive period within the first $75 \mathrm{~min}$ (red symbols) compared to saline-treated mice (black symbols; $n=10)$. $\boldsymbol{E}$, The kainate-induced reduction of LTP amplitude at $12 \mathrm{~h}$ is not present in $\mathrm{fb}-\mathrm{A}_{2 \mathrm{~A}} \mathrm{R}-\mathrm{KO}$ mice $(n=7)$. $\boldsymbol{F}$, Summary of the time-dependent evolution of the impact of a kainate-induced convulsive period on hippocampal synaptic plasticity: LTP was first bolstered (at $4 \mathrm{~h}$ ) and later depressed (at $12 \mathrm{~h}$ ) in a manner strictly dependent on neuronal $A_{2 A} R$ (lack of alterations in fb- $A_{2 A} R-K O$ ). $\boldsymbol{G}, \boldsymbol{H}$, The evolution from overexcitation to decreased synaptic plasticity caused by kainate-induced convulsions was associated with a loss of synaptic markers, namely, SNAP-25, syntaxin-I and vesicular glutamate transporters type 1 (vGluT1), which was seen $12 \mathrm{~h}$ after kainate administration $(n=4)$, but not after $4 \mathrm{~h}$ in wild-type mice (WT; open symbols, $n=4)$ or in fb- $\mathrm{A}_{2 \mathrm{~A}} \mathrm{R}-\mathrm{KO}$ mice (filled symbols, $n=4)$. $\boldsymbol{I}-\boldsymbol{K}$, This putative synaptotoxicity likely involved the recruitment of calpains, which was strictly dependent on the presence of neuronal $A_{2 A} R$ : in fact, kainate triggered a decreased immunoreactivity of the calpain substrate, spectrin (I, $\left.\boldsymbol{J}\right)$, and a parallel increase of the immunodensity of the calpain-derived spectrin breakdown degradation products (SBDP-145-150 kDa) in wild-type but not in fb- $\mathrm{A}_{2 \mathrm{~A}} \mathrm{R}-\mathrm{KO}$ mice $(\boldsymbol{I}, \boldsymbol{K} ; n=5$ in each group). Data are mean $\pm \mathrm{SEM} ; * p<0.05$ between bars or between kainate and saline (SAL) or versus control (100\%). 


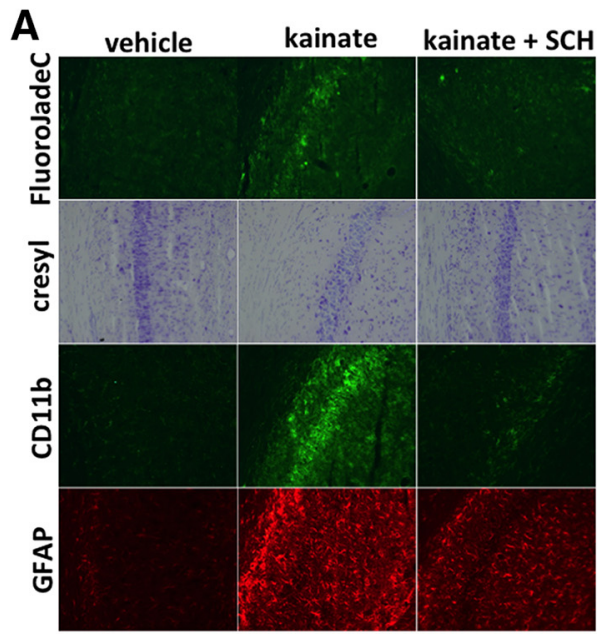

\section{B}

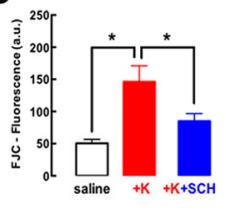

C
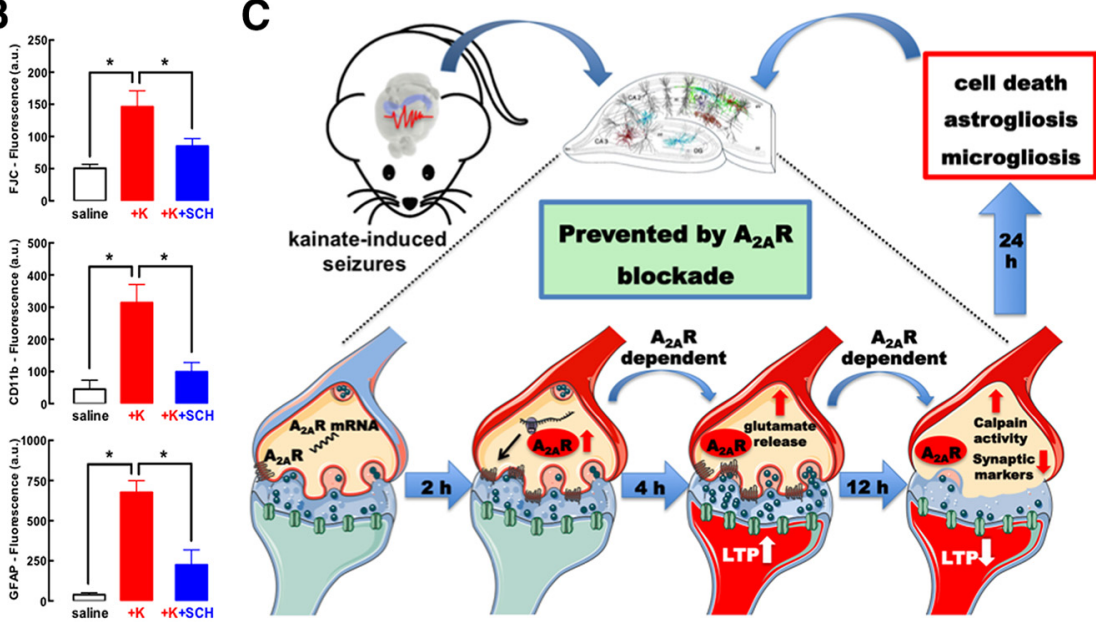

Figure 5. The time window between kainate-induced convulsions and synaptotoxicity and neurodegeneration offers a therapeutic window for $A_{2 A} R$ antagonists to prevent convulsions-induced neurodegeneration. $\boldsymbol{A}$, $\boldsymbol{B}$, The selective $A_{2 A} R$ antagonist $S C H 58261$ $(\mathrm{SCH}, 0.05 \mathrm{mg} / \mathrm{kg})$ applied intraperitoneally $4 \mathrm{~h}$ after kainate-induced convulsions was therapeutically effective to abrogate the emergence of neuronal damage (Nissl staining and FluoroJade-C), microgliosis (CD11b immunoreactivity), or astrogliosis (GFAP immunoreactivity) $24 \mathrm{~h}$ after kainate $(\mathrm{K})$ administration ( $n=5$ mice per group). The data are mean \pm SEM; $* p<0.05$ between the indicated bars. $\boldsymbol{C}$, The pharmacological or genetic blockade of $A_{2 A} R$ did not affect kainate-induced convulsions but dampened the subsequent neurotoxicity. This neurotoxicity began with a rapid $A_{2 A} R$ upregulation in glutamatergic synapses (within $2 \mathrm{~h}$ ), through local translation of synaptic $A_{2 A} R$ mRNA. This bolstered $A_{2 A} R$ facilitation of glutamate release and of LTP in CA1 synapses (4 h), triggered a subsequent synaptotoxicity, heralded by decreased synaptic plasticity and loss of synaptic markers coupled to calpain activation $(12 \mathrm{~h})$, that predated overt neuronal loss accompanied by astrogliosis and microgliosis (24 h). All modifications were prevented by selective $A_{2 A} R$ deletion in forebrain neurons. Overall, this shows that synaptic $A_{2 A} R$ critically control the development of convulsions-induced neurodegeneration.

2.887; df $=14 ; p=0.012 ;$ Fig. $4 D, F)$, which was also abolished $(t=0.1666 ; \mathrm{df}=10 ; p=0.87)$ in forebrain $\mathrm{A}_{2 \mathrm{~A}} \mathrm{R}-\mathrm{KO}$ mice (interaction kainate $\times$ genotype: $F_{(1,24)}=$ $4.588 ; p=0.040$; Fig. $4 E, F)$. In parallel, at $4 \mathrm{~h}$, there was no significant alteration in the density of different synaptic markers (SNAP25: $t=0.580$; df $=6 ; p=0.58$; syntaxin: $t=0.246 ; \mathrm{df}=6 ; p=0.81$; vGluT1: $t=1.423$; df $=6$; $p=0.20$; Fig. $4 G, H)$, contrasting to the decreased density at $12 \mathrm{~h}$ of SNAP25 ( $t=7.313$; df $=6 ; p=0.0003$ ), syntaxin $(t=11.37 ; \mathrm{df}=6 ; p<0.0001)$, and vGluT1 $(t=$ $6.912 ; \mathrm{df}=6 ; p=0.0005$ ) in the hippocampus of kainateversus saline-treated mice (Fig. 4G,H), which was absent in forebrain $\mathrm{A}_{2 \mathrm{~A}} \mathrm{R}-\mathrm{KO}$ mice (SNAP25: $t=0.298$; df $=6$; $p=0.78$; syntaxin: $t=1.227$; df $=6 ; p=0.27$; vGluT1: $t=1.524 ; \mathrm{df}=6 ; p=0.18$; Fig. $4 H$ ). However, although the neurochemical data indicated the presence of synaptotoxic alterations, there was no evidence of overt major morphologic changes in hippocampal section at $12 \mathrm{~h}$ after kainate administration, which displayed a lack of FluoroJadeC staining and no evident alteration of the pattern of GFAP or CD11b immunoreactivity.

\section{$A_{2 A} R$ control the activity of calpains}

Calpains are implicated in epilepsy-associated neurodegeneration (Araújo et al., 2008). Indeed convulsions increased calpain activity in the hippocampus (Fig. 4I), as gauged by the decreased density of the calpain substrate spectrin (Fig. 4I,J; $F_{(1,16)}=20.89 ; p=0.0003$ ) paralleled by the increased density of calpain-derived spectrin breakdown degradation products (SBDP-145-150 kDa; $\left.F_{(1,16)}=8.838 ; p=0.009\right)$, rather than caspase-3-derived
SBDP-120 kDa (Fig. 4I,K). Importantly, both the decrease of spectrin (interaction kainate $\times$ genotype: $F_{(1,16)}=$ $10.98 ; p=0.006)$ and the increase of SBDP-145-150 kDa densities (interaction kainate $\times$ genotype: $F_{(1,16)}=36.41$; $p<0.0001$ ) were not observed in forebrain $A_{2 A} R-K O$ mice (Fig. $4 I, K)$.

\section{Therapeutic prospects of $A_{2 A} R$ antagonists to control convulsions-induced neurodegeneration}

The time course of $A_{2 A} R$-mediated control of glutamate synapses and their subsequent degeneration suggests that there might be a time window for intervention after convulsions to mitigate neurodegeneration by blocking $\mathrm{A}_{2 \mathrm{~A}} \mathrm{R}$. Indeed, SCH58261 $(0.1 \mathrm{mg} / \mathrm{kg})$ administered $4 \mathrm{~h}$ after kainate-induced convulsions (all mice reaching stages 4-5) decreased neuronal damage and microgliosis and attenuated astrogliosis (Fig. $5 A, B$ ). This clearly indicates that $A_{2 A} R$ have a particular role on the evolving processes of neurodegeneration after the convulsive period, which was anticipated based on the lack of alteration of convulsive activity after kainate administration, although the behavioral output of convulsions might not ensure a lack of alteration of any neurophysiological mechanism involved in the insult.

\section{Discussion}

The present study shows that $A_{2 A} R$ are paramount to link convulsions to neurodegeneration. We temporally disentangled different events triggered by kainate-induced convulsions in hippocampal tissue after the extinction of convulsions (Fig. 5C): the first observed event was the 
upregulation of $A_{2 A} R$ in synapses, namely, in glutamatergic synapses (within $2 \mathrm{~h}$ ); this was accompanied by an early increase of glutamatergic activity (within $4 \mathrm{~h}$ ), typified by increased glutamate release and larger synaptic plasticity; in accordance with glutamate-mediated excitotoxicity being a trigger of neurodegeneration (Lipton and Rosenberg, 1994), we observed a later decrease of synaptic plasticity and loss of synaptic markers but no overt neurotoxicity (within $12 \mathrm{~h}$ ) coupled to a calpain activation and overt neuronal damage (within $24 \mathrm{~h}$ ). Our therapeuticlike intervention after the termination of convulsions provides a proof-of-concept to renforce our contention that $A_{2 A} R$ are selectively involved in the control of neurodegeneration after seizures. However, we have not detailed the window of opportunity for intervention with $A_{2 A} R$ antagonists, to define whether $A_{2 A} R$ only control the initial process of excitotoxicity (seen at $6 \mathrm{~h}$, without evidence of synaptotoxicity or overt neurotoxicity) and/or the process of synaptotoxicity (seen at $12 \mathrm{~h}$ without evidence of overt neurotoxicity) and the process of overt neurodegeneration (seen at $24 \mathrm{~h}$ ).

We evaluated kainate-induced toxicity using three different readouts previously described to reflect kainateinduced hippocampal toxicity, namely, cell damage, astrogliosis, and microgliosis (Sperk et al., 1983; Pitkänen and Sutula, 2002; Benkovic et al., 2004). All these degenerative features were prevented by pharmacological or genetic $A_{2 A} R$ inactivation in both rats and mice. This provides strong evidence that the tonic $A_{2 A} R$ activation by endogenous adenosine is crucial to express hippocampal damage following kainate-induced convulsions. In contrast, the role of $A_{2 A} R$ on behavioral seizures is, at best, disputable (El Yacoubi et al., 2001; Etherington and Frenguelli, 2004; Lee et al., 2004; Zeraati et al., 2006; Rosim et al., 2011; Li et al., 2012). Thus, similarly to the effects of caffeine (Rigoulot et al., 2003), $A_{2 A} R$ selectively control hippocampal damage independently of their eventual ability to control the severity of convulsions. This is in accordance with the established role of $A_{2 A} R$ in the control of NMDA receptors and synaptic plasticity processes, rather than to control excitability, which is a function instead fulfilled by $A_{1} R$ (for review, see Cunha, 2016), This prompts $A_{2 A} R$ antagonists as novel "secondary neuroprotective agents" (Meldrum, 2002) arresting the limbic maladaptive plasticity underlying the progressive severity of epilepsy (Meldrum, 2002; Pitkänen and Sutula, 2002; Löscher and Brandt, 2010). However, future studies should evaluate if the manipulation of $A_{2 A} R$ might also alleviate behavioral dysfunction often emerging after seizures, such as cognitive impairments that are controlled by $A_{2 A} R$ in different brain disorders (for review, see Cunha, 2016).

Although $A_{2 A} R$ are located in neurons as well as in glia (Cunha, 2016), the use of forebrain $A_{2 A} R-K O$ mice provided direct evidence that it is $A_{2 A} R$ in neurons that critically control kainate-induced neurodegeneration. Thus, the deletion of neuronal $A_{2 A} R$ is sufficient to fully account for the role of $A_{2 A} R$ in the development of neurodegeneration following seizures and further studies should clarify if $A_{2 A} R$ in microglia and/or astrocytes might also play an ancillary role in seizures-induced neurodegeneration. Cerebral cortical $A_{2 A} R$ are most abundantly located in synapses (Rebola et al., 2005b) with a low density in physiologic conditions (Lopes et al., 2004), as expected from a receptor selectively involved in bolstering synaptic plasticity (Rebola et al., 2008; Costenla et al., 2011). Probably as an attempt to increase adaptability after injury, $A_{2 A} R$ are upregulated after brain insults (Cunha, 2016), namely, in epilepsy models (Rebola et al., 2005a) and patients (Barros-Barbosa et al., 2016). The mechanisms linking brain insults to $A_{2 A} R$ upregulation are unknown, since the regulation of the promoter(s) of the $A_{2 A} R$ gene and of its numerous transcripts encoding $A_{2 A} R$ are still poorly understood (Lee et al., 2003; Yu et al., 2004). The present study reveals some surprising novel findings. First, we identified $A_{2 A} R$ transcripts in synapses, where a local translation seems sufficient to account for synaptic $A_{2 A} R$ upregulation. Second, we found that synaptic $A_{2 A} R$ upregulation on brain dysfunction is a rapid event, occurring in less than $2 \mathrm{~h} . \mathrm{A}_{2 \mathrm{~A}} \mathrm{R}$ upregulation is well positioned to trigger a transient hyperfunction of glutamatergic synapses, which is involved in the pathophysiology of most neurodegenerative disorders (Lipton and Rosenberg, 1994), since hippocampal $A_{2 A} R$ bolster glutamate release (Lopes et al., 2002), NMDA receptor function (Rebola et al., 2008), and calcium influx in synapses (Gonçalves et al., 1997). Furthermore, we now show that $A_{2 A} R$ activity is strictly required to trigger calpain activity that was previously shown to mediate kainate-induced neurodegeneration (Araújo et al., 2008).

These early synaptic modifications match the recognition of synapses as initial triggers of neurodegeneration in other neurodegenerative conditions such as Alzheimer's disease (Selkoe, 2002), with a predominant early alteration of glutamatergic synapses (Kirvell et al., 2006; Canas et al., 2014). Accordingly, animal models and epileptic patients with sclerosis display a loss of synaptic markers (Looney et al., 1999; Zhang et al., 2014), in particular of glutamatergic markers (Alonso-Nanclares and De Felipe, 2005; van der Hel et al., 2009). This is compatible with the engagement of glutamate-mediated excitotoxicity, involving NMDA receptor activation and excessive calcium influx to activate calpains to destroy glutamatergic synapses before the emergence of overt neuronal death (Cunha, 2016), through mechanisms where glia cells likely participate (Pitkänen and Sutula, 2002; Devinsky et al., 2013).

This conclusion that $A_{2 A} R$ activation is paramount for the development of convulsions-induced neurodegeneration prompts reevaluating the concept of adenosine as an anti-epileptic agent (Dragunow, 1988; Dunwiddie, 1999). The action of adenosine through $A_{1} R$ lowers seizure onset acting as anti-convulsive (Dragunow, 1988; Dunwiddie, 1999), but $A_{1} R$ undergo a rapid desensitization after convulsions (Young and Dragunow, 1994; Ochiishi et al., 1999; Rebola et al., 2003). The present observation that the tonic $A_{2 A} R$ activation by endogenous adenosine plays a pivotal role for the expression of damage in hippocampal tissue after a convulsive period, shows that the role of adenosine in the control of epilepsy may be more com- 
plex than previously proposed. Thus, adenosine plays a bi-phasic role in the control of epilepsy, lessening convulsive episodes but bolstering subsequent damage. This newly identified selective role of $A_{2 A} R$ in the control of the neurodegeneration that develops as a consequence but after the convulsive period (Sperk et al., 1983; Pitkänen and Sutula, 2002) heralds the concepts of $A_{2 A} R$ blockade as a new therapeutic strategy to arrest the evolution of epilepsy. Indeed, $A_{2 A} R$ blockade attenuated amygdala- or pentylenetetrazol-induced kindled seizures (El Yacoubi et al., 2009), two models of slowly developing convulsions. Furthermore, we now showed that the administration of a selective $A_{2 A} R$ antagonist after the convulsive period was still effective to arrest the subsequent hippocampal damage. This is in agreement with the reported ability of $A_{2 A} R$ antagonists to prevent the long-term development of behavioral abnormalities in adult rats after convulsions early in life (Cognato et al., 2010). Also, genetic polymorphisms of $A_{2 A} R$ (ADORA2A) are associated with childhood encephalopathy resulting from biphasic seizures (Shinohara et al., 2013). Together, this evidence heralds the new concept that $A_{2 A} R$ are paramount for the development of neurodegeneration after convulsions.

\section{References}

Alonso-Nanclares L, De Felipe $\mathrm{J}$ (2005) Vesicular glutamate transporter 1 immunostaining in the normal and epileptic human cerebral cortex. Neuroscience 134:59-68. CrossRef Medline

Araújo IM, Gil JM, Carreira BP, Mohapel P, Petersen A, Pinheiro PS, Soulet D, Bahr BA, Brundin P, Carvalho CM (2008) Calpain activation is involved in early caspase-independent neurodegeneration in the hippocampus following status epilepticus. J Neurochem 105:666-676. CrossRef Medline

Barros-Barbosa AR, Ferreirinha F, Oliveira Â, Mendes M, Lobo MG, Santos A, Rangel R, Pelletier J, Sévigny J, Cordeiro JM, Correiade-Sá $P$ (2016) Adenosine $A_{2 A}$ receptor and ecto-5'-nucleotidase/ CD73 are upregulated in hippocampal astrocytes of human patients with mesial temporal lobe epilepsy (MTLE). Purinergic Signal 12:719-734. CrossRef Medline

Ben-Ari Y (1985) Limbic seizure and brain damage produced by kainic acid: mechanisms and relevance to human temporal lobe epilepsy. Neuroscience 14:375-403. CrossRef Medline

Benkovic SA, O'Callaghan JP, Miller DB (2004) Sensitive indicators of injury reveal hippocampal damage in C57BL/6J mice treated with kainic acid in the absence of tonic-clonic seizures. Brain Res 1024:59-76. CrossRef Medline

Berman RF, Fredholm BB, Aden U, O'Connor WT (2000) Evidence for increased dorsal hippocampal adenosine release and metabolism during pharmacologically induced seizures in rats. Brain Res 872: 44-53. Medline

Boison D (2016) Adenosinergic signaling in epilepsy. Neuropharmacology 104:131-139. CrossRef Medline

Canas PM, Simões AP, Rodrigues RJ, Cunha RA (2014) Predominant loss of glutamatergic terminal markers in a $\beta$-amyloid peptide model of Alzheimer's disease. Neuropharmacology 76:51-56. CrossRef Medline

Chen JF, Sonsalla PK, Pedata F, Melani A, Domenici MR, Popoli P, Geiger J, Lopes LV, de Mendonça A (2007) Adenosine $A_{2 A}$ receptors and brain injury: broad spectrum of neuroprotection, multifaceted actions and "fine tuning" modulation. Prog Neurobiol 83:310331. CrossRef Medline

Cognato GP, Agostinho PM, Hockemeyer J, Müller CE, Souza DO, Cunha RA (2010) Caffeine and an adenosine $A_{2 A}$ receptor antagonist prevent memory impairment and synaptotoxicity in adult rats triggered by a convulsive episode in early life. J Neurochem 112: 453-462. CrossRef Medline
Costenla AR, Diógenes MJ, Canas PM, Rodrigues RJ, Nogueira C, Maroco J, Agostinho PM, Ribeiro JA, Cunha RA, de Mendonça A (2011) Enhanced role of adenosine $A_{2 A}$ receptors in the modulation of LTP in the rat hippocampus upon ageing. Eur $\mathrm{J}$ Neurosci 34:12-21. CrossRef Medline

Coyle JT (1987) Kainic acid: insights into excitatory mechanisms causing selective neuronal degeneration. Ciba Found Symp 126: 186-203. Medline

Cunha RA (2005) Neuroprotection by adenosine in the brain: from $A_{1}$ receptor activation to $A_{2 A}$ receptor blockade. Purinergic Signal 1:111-134. CrossRef Medline

Cunha RA (2016) How does adenosine control neuronal dysfunction and neurodegeneration? J Neurochem 139:1019-1055. CrossRef Medline

Dalmau I, Vela JM, González B, Finsen B, Castellano B (2003) Dynamics of microglia in the developing rat brain. J Comp Neur 458:144-157. CrossRef Medline

Devinsky O, Vezzani A, Najjar S, De Lanerolle NC, Rogawski MA (2013) Glia and epilepsy: excitability and inflammation. Trends Neurosci 36:174-184. CrossRef Medline

Dragunow M (1988) Purinergic mechanisms in epilepsy. Prog Neurobiol 31:85-108. Medline

Dunwiddie TV (1999) Adenosine and suppression of seizures. Adv Neurol 79:1001-1010. Medline

During MJ, Spencer DD (1992) Adenosine: a potential mediator of seizure arrest and postictal refractoriness. Ann Neurol 32:618624. CrossRef Medline

El Yacoubi M, Ledent C, Parmentier M, Daoust M, Costentin J, Vaugeois $J$ (2001) Absence of the adenosine $A_{2 A}$ receptor or its chronic blockade decrease ethanol withdrawal-induced seizures in mice. Neuropharmacology 40:424-432. Medline

El Yacoubi M, Ledent C, Parmentier M, Costentin J, Vaugeois JM (2009) Adenosine $A_{2 A}$ receptor deficient mice are partially resistant to limbic seizures. Naunyn Schmiedebergs Arch Pharmacol 380: 223-232. CrossRef Medline

Etherington LA, Frenguelli BG (2004) Endogenous adenosine modulates epileptiform activity in rat hippocampus in a receptor subtype-dependent manner. Eur J Neurosci 19:2539-2550. CrossRef Medline

Fedele DE, Li T, Lan JQ, Fredholm BB, Boison D (2006) Adenosine A receptors are crucial in keeping an epileptic focus localized. Exp Neurol 200:184-190. CrossRef Medline

Gonçalves ML, Cunha RA, Ribeiro JA (1997) Adenosine $A_{2 A}$ receptors facilitate ${ }^{45} \mathrm{Ca}^{2+}$ uptake through class $A$ calcium channels in rat hippocampal CA3 but not CA1 synaptosomes. Neurosci Lett 238:73-77. CrossRef Medline

Gouder N, Fritschy JM, Boison D (2003) Seizure suppression by adenosine $A_{1}$ receptor activation in a mouse model of pharmacoresistant epilepsy. Epilepsia 44:877-885. CrossRef Medline

Kaster MP, Machado NJ, Silva HB, Nunes A, Ardais AP, Santana M, Baqi Y, Müller CE, Rodrigues AL, Porciúncula LO, Chen JF, Tomé ÂR, Agostinho P, Canas PM, Cunha RA (2015) Caffeine acts through neuronal adenosine $A_{2 A}$ receptors to prevent mood and memory dysfunction triggered by chronic stress. Proc Natl Acad Sci USA 112:7833-7838. CrossRef Medline

Kirvell SL, Esiri M, Francis PT (2006) Down-regulation of vesicular glutamate transporters precedes cell loss and pathology in Alzheimer's disease. J Neurochem 98:939-950. CrossRef Medline

Lee YC, Chien CL, Sun CN, Huang CL, Huang NK, Chiang MC, Lai HL, Lin YS, Chou SY, Wang CK, Tai MH, Liao WL, Lin TN, Liu FC, Chern $Y(2003)$ Characterization of the rat $A_{2 A}$ adenosine receptor gene: a 4.8-kb promoter-proximal DNA fragment confers selective expression in the central nervous system. Eur J Neurosci 18:17861796. Medline

Lee HK, Choi SS, Han KJ, Han EJ, Suh HW (2004) Roles of adenosine receptors in the regulation of kainic acid-induced neurotoxic responses in mice. Mol Brain Res 125:76-85. CrossRef Medline

Li X, Kang H, Liu X, Liu Z, Shu K, Chen X, Zhu S (2012) Effect of adenosine $A_{2 A}$ receptor antagonist ZM241385 on amygdala- 
kindled seizures and progression of amygdala kindling. J Huazhong Univ Sci Technol Med Sci 32:257-264. CrossRef Medline

Lipton SA, Rosenberg PA (1994) Excitatory amino acids as a final common pathway for neurologic disorders. N Engl J Med 330: 613-622. CrossRef Medline

Looney MR, Dohan FC Jr, Davies KG, Seidenberg M, Hermann BP, Schweitzer JB (1999) Synaptophysin immunoreactivity in temporal lobe epilepsy-associated hippocampal sclerosis. Acta Neuropathol 98:179-185. Medline

Lopes LV, Cunha RA, Kull B, Fredholm BB, Ribeiro JA (2002) Adenosine $A_{2 A}$ receptor facilitation of hippocampal synaptic transmission is dependent on tonic $A_{1}$ receptor inhibition. Neuroscience 112:319-329. CrossRef Medline

Lopes LV, Halldner L, Rebola N, Johansson B, Ledent C, Chen JF, Fredholm BB, Cunha RA (2004) Binding of the prototypical adenosine $A_{2 A}$ receptor agonist CGS 21680 to the cerebral cortex of adenosine $A_{1}$ and $A_{2 A}$ receptor knockout mice. $\mathrm{Br} \mathrm{J}$ Pharmacol 141:1006-1014. CrossRef Medline

Löscher W, Brandt C (2010) Prevention or modification of epileptogenesis after brain insults: experimental approaches and translational research. Pharmacol Rev 62:668-700. CrossRef Medline

Marchi M, Raiteri L, Risso F, Vallarino A, Bonfanti A, Monopoli A, Ongini $E$, Raiteri $M(2002)$ Effects of adenosine $A_{1}$ and $A_{2 A}$ receptor activation on the evoked release of glutamate from rat cerebrocortical synaptosomes. Br J Pharmacol 136:434-440. CrossRef Medline

Meldrum BS (2002) Implications for neuroprotective treatments. Prog Brain Res 135:487-495. CrossRef Medline

Ochiishi T, Takita M, Ikemoto M, Nakata H, Suzuki SS (1999) Immunohistochemical analysis on the role of adenosine $A_{1}$ receptors in epilepsy. Neuroreport 10:3535-3541. Medline

Ogawa Y, Furusawa E, Saitoh T, Sugimoto H, Omori T, Shimizu S, Kondo H, Yamazaki M, Sakuraba H, Oishi K (2018) Inhibition of astrocytic adenosine receptor $A_{2 A}$ attenuates microglial activation in a mouse model of Sandhoff disease. Neurobiol Dis 118:142154. CrossRef Medline

Orr AG, Orr AL, Li XJ, Gross RE, Traynelis SF (2009) Adenosine A $A_{2 A}$ receptor mediates microglial process retraction. Nat Neurosci 12: 872-878. CrossRef Medline

Orr AG, Hsiao EC, Wang MM, Ho K, Kim DH, Wang X, Guo W, Kang J, Yu GQ, Adame A, Devidze N, Dubal DB, Masliah E, Conklin BR, Mucke $L$ (2015) Astrocytic adenosine receptor $A_{2 A}$ and $G_{s}$-coupled signaling regulate memory. Nat Neurosci 18:423-434. CrossRef Medline

Pinto MJ, Alves PL, Martins L, Pedro JR, Ryu HR, Jeon NL, Taylor AM, Almeida RD (2016) The proteasome controls presynaptic differentiation through modulation of an on-site pool of polyubiquitinated conjugates. J Cell Biol 212:789-801. CrossRef Medline

Pitkänen A, Sutula TP (2002) Is epilepsy a progressive disorder? Prospects for new therapeutic approaches in temporal-lobe epilepsy. Lancet Neurol 1:173-181. CrossRef Medline

Rebola N, Coelho JE, Costenla AR, Lopes LV, Parada A, Oliveira CR, Soares-da-Silva P, de Mendonça A, Cunha RA (2003) Decrease of adenosine $A_{1}$ receptor density and of adenosine neuromodulation in the hippocampus of kindled rats. Eur J Neurosci 18:820-828. Medline

Rebola N, Porciúncula LO, Lopes LV, Oliveira CR, Soares-da-Silva P, Cunha RA (2005a) Long-term effect of convulsive behavior on the density of adenosine $A_{1}$ and $A_{2 A}$ receptors in the rat cerebral cortex. Epilepsia 46 [Suppl 5]:159-165. CrossRef

Rebola N, Canas PM, Oliveira CR, Cunha RA (2005b) Different synaptic and subsynaptic localization of adenosine $A_{2 A}$ receptors in the hippocampus and striatum of the rat. Neuroscience 132: 893-903. CrossRef Medline
Rebola N, Lujan R, Cunha RA, Mulle C (2008) Adenosine $A_{2 A}$ receptors are essential for long-term potentiation of NMDA-EPSCs at hippocampal mossy fiber synapses. Neuron 57:121-134. CrossRef Medline

Rebola N, Simões AP, Canas PM, Tomé AR, Andrade GM, Barry CE, Agostinho PM, Lynch MA, Cunha RA (2011) Adenosine $A_{2 A}$ receptors control neuroinflammation and consequent hippocampal neuronal dysfunction. J Neurochem 117:100-111. CrossRef Medline

Rigoulot MA, Leroy C, Koning E, Ferrandon A, Nehlig A (2003) Prolonged low-dose caffeine exposure protects against hippocampal damage but not against the occurrence of epilepsy in the lithium-pilocarpine model in the rat. Epilepsia 44:529-535. CrossRef Medline

Rosim FE, Persike DS, Nehlig A, Amorim RP, de Oliveira DM, Fernandes MJ (2011) Differential neuroprotection by $A(1)$ receptor activation and $A_{2 A}$ receptor inhibition following pilocarpineinduced status epilepticus. Epilepsy Behav 22:207-213. CrossRef Medline

Selkoe DJ (2002) Alzheimer's disease is a synaptic failure. Science 298:789-791. CrossRef Medline

Shen HY, Coelho JE, Ohtsuka N, Canas PM, Day YJ, Huang QY, Rebola N, Yu L, Boison D, Cunha RA, Linden J, Tsien JZ, Chen JF (2008) A critical role of the adenosine $A_{2 A}$ receptor in extrastriatal neurons in modulating psychomotor activity as revealed by opposite phenotypes of striatum and forebrain $A_{2 A}$ receptor knock-outs. J Neurosci 28:2970-2975. CrossRef Medline

Shinohara M, Saitoh M, Nishizawa D, Ikeda K, Hirose S, Takanashi J, Takita J, Kikuchi K, Kubota M, Yamanaka G, Shiihara T, Kumakura A, Kikuchi M, Toyoshima M, Goto T, Yamanouchi H, Mizuguchi M (2013) ADORA2A polymorphism predisposes children to encephalopathy with febrile status epilepticus. Neurology 80:1571-1576. CrossRef Medline

Sperk G, Lassmann H, Baran H, Kish SJ, Seitelberger F, Hornykiewicz O (1983) Kainic acid induced seizures: neurochemical and histopathological changes. Neuroscience 10:1301-1315. Medline Taylor AM, Blurton-Jones M, Rhee SW, Cribbs DH, Cotman CW, Jeon NL (2005) A microfluidic culture platform for CNS axonal injury, regeneration and transport. Nat Methods 2:599-605. CrossRef Medline

van der Hel WS, Verlinde SA, Meijer DH, de Wit M, Rensen MG, van Gassen KL, van Rijen PC, van Veelen CW, de Graan PN (2009) Hippocampal distribution of vesicular glutamate transporter 1 in patients with temporal lobe epilepsy. Epilepsia 50:1717-1728. CrossRef Medline

von Lubitz DK (2001) Adenosine in the treatment of stroke: yes, maybe, or absolutely not? Expert Opin Invest Drugs 10:619-632. CrossRef Medline

Young D, Dragunow M (1994) Status epilepticus may be caused by loss of adenosine anticonvulsant mechanisms. Neuroscience 58: 245-261. Medline

Yu L, Frith MC, Suzuki Y, Peterfreund RA, Gearan T, Sugano S, Schwarzschild MA, Weng Z, Fink JS, Chen JF (2004) Characterization of genomic organization of the adenosine $A_{2 A}$ receptor gene by molecular and bioinformatics analyses. Brain Res 1000: 156-173. CrossRef Medline

Zeraati M, Mirnajafi-Zadeh J, Fathollahi Y, Namvar S, Rezvani ME (2006) Adenosine $A_{1}$ and $A_{2 A}$ receptors of hippocampal CA1 region have opposite effects on piriform cortex kindled seizures in rats. Seizure 15:41-48. CrossRef Medline

Zhang FX, Sun QJ, Zheng XY, Lin YT, Shang W, Wang AH, Duan RS, Chi ZF (2014) Abnormal expression of synaptophysin, SNAP-25, and synaptotagmin 1 in the hippocampus of kainic acid-exposed rats with behavioral deficits. Cell Mol Neurobiol 34:813-824. CrossRef Medline 